Copyright (C) 2016 by Academic Publishing House Researcher

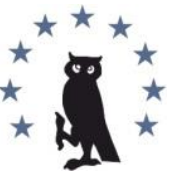

Published in the Russian Federation

European Researcher

Has been issued since 2010.

ISSN 2219-8229

E-ISSN 2224-0136

Vol. 109, Is. 8, pp. 456-461, 2016

DOI: 10.13187/er.2016.109.456

www.erjournal.ru

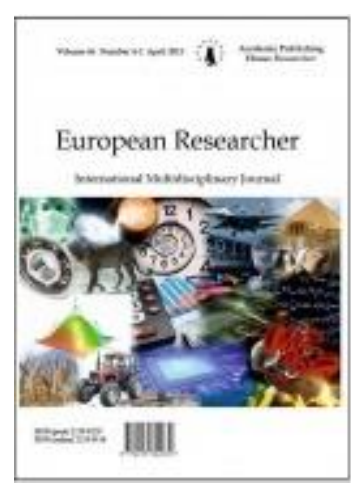

UDC 930.85

\title{
Religious Studies and Anti-Religious Propaganda in USSR in 1920-1930s
}

\author{
Marianna M. Shakhnovich
}

Saint-Petersburg State University, Russian Federation

Mendeleevskaya liniya 5, St. Petersburg 199034

Dr. (Philosophy), Professor

E-mail:m.shakhnovich@spbu.ru

\begin{abstract}
The article shows, that in 1920-1930 simultaneously with the anti-religious propaganda, the history of world religions and religious movements, anthropological and sociological studies of religion, the history of religious freethinking and atheism were carried out. The systematic work on the study of the religious beliefs and practices in everyday life has been designed and created on the basis of large scale field research in accordance with the achievements of modern theoretical works. There were two groups inside the academic community with opposite views on the nature and sense of religious studies: one group, explored the opportunity to make the research without clerical censorship, wanted to study religion as a cultural phenomenon, using different methodological approaches including Marxism, and understood the expression "critique of religion" in the philosophical sense as a historical and sociological analysis. The majority of them did not deny the Marxist idea of the gradual disappearance of religion in secularized world. Another group - of left political radicals - sought only to expose religion, looking for evidence of possible exposure. Among the works on the history of religion, published in the Soviet period, it is necessary to distinguish between the works done with the exclusive purpose for propaganda, from the works in which the free investigation and academic research might be found inside the ideologically and politically correct chains of that time.
\end{abstract}

Keywords: religious studies, anti-religious propaganda in USSR, ethnography, anthropology.

\section{Introduction}

The problem of the relationship of science and power is one of the most pressing issues discussed in the last fifty years by the philosophers and sociologists from Michel Foucault ("Archaeology of Knowledge", 1969 and "Discipline and Punish", 1975) to Bruno Latour ("Science in Action", 1987), as well as by historians and sociologists of science. The different aspects of the relations of science, humanities and ideology during Soviet period have been thoroughly analyzed already, except religious studies and its history. Was it possible for the science of religion to survive in the atmosphere of anti-religious propaganda and the repression towards religious organizations and believers? Here and there during the last several years in some publications, especially in the texts of the authors whose research interest laid only in the history of the prosecution of the believers in Soviet period one may read that there was no study of religion in Soviet Union in 1920- 
1930 s and there was only the anti-religious propaganda [1]. But it is not true to facts. The end of 1920 s to and the beginning of 1930 s was a very important period in the history of Russian science of religion. A large group of scholars, historians and anthropologists mainly, promoted their research. At that time, simultaneously with the anti-religious propaganda, the history of world religions and religious movements, anthropological and sociological studies of religion, the history of religious freethinking and atheism were carried out. The desire of scholars to study religion and preserve religious artefacts as cultural assets clashed with the views of the Party's ideologists, which saw any research into religion as advocating its practice. Sometimes only way out was to explain the need to study religion in order to debunk it, and phrases about antireligious propaganda often became an 'ideological justification' for the scientific research. The systematic work on the study of the religious beliefs and practices in everyday life has been designed and created on the basis of large scale field research in accordance with the achievements of modern theoretical works.

\section{Materials and Methods}

The article is based on the archival materials, first of all, on the funds of the Archive of the Russian Academy of Science, as well as on the printed materials of the time. One of the methodological principles of research is to review the anti-religious propaganda as clearly structured purposeful spiritual influence, the practice of using the discipline and control of thinking and behavior that have been previously characterized only to the religious institutions, but found a new life in an era of cultural development of the 1920s. An important part of the study is the consideration of the "epistemic" principles of anti-religious propaganda associated with the idea of a constant "struggle of ideas" and the need to participate in it.

\section{Discussion}

Since the 1990s, many documents on the complex relations between the state and religious associations in the Soviet period were published, revealing the tragic pages of the history of persecution for religious beliefs. However, despite the interest in critical reflection of the process of formation of the Soviet ideological model, the modern researchers did not look over the possibility of religious studies in the context of the overall objectives of the Soviet cultural development, focusing mainly on its "destructive" aspect in anti-religious propaganda.

To understand the public mood and intellectual atmosphere of the era, it is important not to break away from the historical context, to understand the characteristics not only of the ideological clichés, but also of polemical discourse. One ought to analyze not only official documents of the period, but also personal documents - letters, diaries. For example, a writer and scholar Lydia Ginzburg wrote in her diary in 1928: "At the moment it is wrong to divide our historians into those who use sociological methods, and those who do not use them. We should be divided into those, whose sociological methods are immediately rewarded by higher positions, money and glory, and those, whose sociological methods are not rewarded" $[2,30]$. At that time the social and anthropological approaches were the main stream of the study of religion in Soviet country as well as in the same studies in Europe. Among the scholars of that time we may see the followers of Weber and Durkheim, as well as supporters of Neo-Kantianism, Cassirer mainly, as well as those whose interest laid in social psychology of Levi-Bruhl [3]. Naturally, some of the scholars were atheists, some of them were agnostics, but they support the principle of freedom of conscience, which they regarded not only as religious freedom, but also as the right to be an unbeliever. Some of them, as we got to know now, were religious people, but both atheists and believers, perceived the "antireligious propaganda" of 1920-1930s and the "scientific atheism" of 1960-1980s as ideological norms, imposed from above, as the result of ongoing Cultural Revolution.

The aim of the Soviet cultural revolution of 1920-1930 was to create a "new human being", who completely "has thrown off religious chains". Implementation of this idea began in 1922 after the publication of Lenin's article "On the Significance of Militant Materialism", which identified the main directions of the upcoming ideological work. One of the important tools for the implementation of the project for "creation of a new man" free from religion, was the periodical press, and, first of all, the newspaper "Bezbojnik" (Atheist). From the Society of Friends of the newspaper "Bezbojnik" in 1925 the Atheists Union was organized. It was a public organization 
united together youth activists, agitators and party propagandists. In the new situation of the separation of church and state and school from the church and the secularization of church and monastic estates, the main task of that organization was the struggle for non-religious way of life and a new culture, education, science and public life free from religious influence and censorship. In July 1918, the Constitution of the RSFSR for the first time in the history of Russia fixed by law the right of a citizen to be a nonbeliever or an atheist.

In 1922, on October 30 in Minsk at the ceremonial meeting of the Belarusian University the famous specialist in the field of primitive beliefs and religions of the ancient world, Nicolas Nikolsky in his report "Religion as a subject of science" described the science of religion (religious studies) as a young scientific discipline that emerged in the late 19 century, designed to solve the deep problems of cultural history and had a great future. He stressed that the freedom was needed for the non-stop development of that new science. It might have the possibility to flourish only in the society with the freedom of consciousness. The historians of religion ought to have not only formal, but completely real possibility to do their studies, as well as chemists, physicists, mathematicians, linguists and ethnologists without any pressing of church and state. As we know now his expectations were not realized. Russian science of religion was born in imperial Russia, when there was the church ideological censorship and developed under the Soviet censorship.

Of course, the regiment of vulgar sociological views was very heavy in the religious studies of the 1920-1930s. In the majority of texts published in the Soviet Union, the point of view that religion in society depended on the interests of certain social groups and classes, and linked to their political and ideological struggle prevailed. However, it was believed that religion had certain independence and economic reasons did not directly cause changes in its development, on the contrary, it may influence the changing of the economic base. The study of every religion was implied in the context of specific historical conditions and in connection with the study of the society in which it functioned. Of course, all the works in the field of social sciences and humanities bore the stamp of the era, which manifested itself in linguistic clichés, methodological approaches, and cited authorities. However, among the works on the history of religion, published in the Soviet period, it is necessary to distinguish between the works done with the exclusive purpose for propaganda, from the works in which the free investigation and academic research might be found inside the ideologically and politically correct chains of that time.

From two and a half thousand books and articles listed in the catalog "Soviet anti-religious literature from 1917 to 1930 ", more than $30 \%$ of publications were done as a serious academic study [4; 5;6]. Within the so-called "Soviet Religious studies" has never been a complete ideological unity, and that is why it is impossible to smear all the authors writing about religion the same paint. You may find a lot documentary evidence that the contradictions between those, who engaged exclusively in anti-religious propaganda, and those, who wanted to carry out scientific research, arose systematically in 1920-1930 as well as in Khrushchov's time. For example, a wellknown propagator of antireligious ideas S.L.Ursynovich in 1928 stated: "We should ... raise the issue of the need to have such ethnographic studies in which ethnographers at the same time will serve to the objectives of the anti-religious movement. For us it is difficult to find it now. ... This summer, I had to go on an expedition to the Crimea to one of our ethnographers; I need him to assist me for collecting of materials. When he learned, that antireligioznik (anti-religious activist) arrived, he said that he had finished his field work already, and he did not have any opportunity to help me" [7, 33].

Some modern authors name both V.V. Bonch-Bruevich and F.M. Putintsev who published texts on sectarianism in 1920-1930s "scholars" [8, 120-121], but the difference in their approach is easy to figure out just to open their books, or look through the archival materials showing the ideological discussions of the time. For example, in 1928 F.M. Putintsev at a meeting of the Communist Academy in Moscow stated the following: "When we ask comrade Bonch-Bruevich, how he is looking at sectarians, Bonch-Bruevich says that, despite of all the shortcomings, he believes that the sectarians belong to the best part of the Russian people. More populist answer is impossible to imagine. What does it mean? Do we have the poor? We have. Do we have kulaki (reach peasants)? Yes, we do. So why now, when at the head of the sectarians there are kulaki, when we ask Bonch-Bruevich to oppose sects, he cannot. When the Party entrusted BonchBruevich to protect the sects from the priests and from the state church and gendarmes, he defended them superbly. And when sectarians try to use their activity against us, when there are 
kulaki between the sectarians, who play a huge role and they are against us, we do not find support from Bonch-Bruevich personally" [9, 39]. Another political activist, the editor in chief of the magфsine "Atheist at the machine" I.N. Stukov put it more clearly: "You cannot say that the sects are not our enemies. No, they are our enemies, it is definitely our enemies. "The sectariandemocrat", as the bearer of the democratic (i.e., bourgeois) values is the enemy of the socialist proletarian revolution. Bonch-Bruevich is in trouble - the profession has left its mark on him, and he became a kind of sectarian by himself" [9, 97-98].

One of the most vivid example of the development of the academic studies of religion in the middle of the 1930 s is the activity of the research group headed by Nikolai Mikhailovich Matorin (1898-1936), who played a particularly important role in the planning, organisation and conduct of research into the religious beliefs and faiths of the various peoples of the USSR.

From the autumn of 1928 until December 1934 Matorin was the main organiser and inspiratory for research into religion in Leningrad, working in various areas: education, the collection of materials, exhibitions, research and propaganda. In 1930 Matorin became director of the Museum of the Anthropology and Ethnography, and in 1933 he was elected director of the USSR Academy of Sciences' Institute of Anthropology and Ethnography. Matorin organised, as was customary at the time, a research group (or panel) to study the history of so-called 'cults', i.e. everyday religiosity. Members of the group met regularly for evening sessions in the faculty of geography of Leningrad University. Lecturers, students, museum workers and propagandists from the League of Militant Atheists took part in the sessions, many coming especially for the event from different regions of the USSR. The backbone of the group consisted of Matorin's closest fellow workers and students, as well as colleagues of his that were working on similar issues.

The group changed its name and place of 'residence' several times, to suit the convenience of its director, who, like many scholars in those years, was working at several institutions at once. From Leningrad University, the group meetings moved first to the State Academy for the History of Material Culture, where in August 1929 Matorin was employed as a researcher, and then to the Institute for the Study of the Peoples of the, where Matorin was appointed deputy director. In September 1934 the group moved under the aegis of the Museum of the History of Religion, changing its name to the 'Panel for the Study of the Religions of the Peoples of the USSR'.

This is what Vladimir Bogoraz-Tan, director of the MHR, wrote about the work of Matorin's research group: "The panel predominantly focused its attention on the study of religious syncretism, and engaged a series of historians of religion, ethnographers, archaeologists and folklorists in its work. In addition, the panel built up a significant network of correspondents, made up of researchers across the USSR, particularly in the national republics and the regions, with whom an extremely vibrant, constant connection was forged. Branches of the panel have been formed in Moscow (at the Central Antireligious Museum), Kalinin, Voronezh and Cheboksary. The panel is continuing its work of many years to map everyday religion in various regions of the country (Chuvash keremets, Ossetian dzuars, pre-Christian sacred groves in the Leningrad, Moscow, Voronezh and Northern regions, etc.). The panel has compiled two collections of articles from papers read at its meetings: 'Religious Syncretism' and 'Religious Beliefs in the Leningrad Region" " [10, 13-14].

It is necessary to tell that by the mid-1920s there were two groups inside the academic community with opposite views on the nature and sense of religious studies: one group, explore the opportunity to make the research without clerical censorship, wanted to study religion, using different methodological approaches including Marxism, and understood the expression "critique of religion" in the philosophical sense as a historical and sociological analysis (the majority of them did not deny the Marxist idea of the gradual disappearance of religion in secularized world), and another group - of left political radicals - sought only to expose religion, looking for evidence of possible exposure.

\section{Conclusion}

In conclusion, we want to say, that while speaking about the influence of atheistic ideology on the humanities in Russia it is necessary to speak about the specific transformation of the Enlightening project. The result of the implementation of that project, whether it was victorious or failure, is a topic of another discussion. But we need to look on the history of Soviet religious 
studies in the context of the secularization process started in Europe in 16th century, which gave the scholars the possibility to study religion without any preconditions, due to the freedom of consciousness, which is not only the religious freedom but the freedom to be a nonbeliever.

\title{
Acknowledgements
}

The publication was prepared with the support of the grant of Russian Science Foundation № 16-18-10083 "The Study of Religion in Social and Cultural Context of the Epoch: the History Religious Studies and Intellectual History of Russia 19th- first half of 2oth century".

\section{References}

1. Shakhnovich M.M. Ehtos istorii nauki: o rekonstrukcii rossijskogo religiovedeniya sovetskogo perioda. [The ethos of the history of science: the reconstruction of the Russian Soviet period] // Gosudarstvo, religiya i tserkov'v Rossii i za rubezhom 2015. № 1. P. 185-198.

2. Sawitzki S.A. Chastnyj chelovek. L.Ya. Ginzburg v konce 1920-h-nachale-1930-h godov. [Private person. L. Ginzburg in the late 1920s and early 1930s.] St. Petersburg, 2013.

3. Shakhnovich M.M. Ocherki istorii religiovedeniya. [Essays on the history of religion.] St. Petersburg: St. Petersburg State University, 2006.

4. Glan Ya. Antireligiosnaya litreatura za 12 let. [Anti-religious literature for 12 years (19171929)]. M., 1930.

5. Glan Ya. Antireligiosnaya litreatura. Oktjabrskii period. [Anti-religious literature. October period (1929-1930)]. M., 1930.

6. GlanYa. Antireligiosnaya litreatura. Pooktjabrskiiperiod. [Anti-religious literature. After October period.] M., 1932.

7. Arkhiv Rossiiskoi Akademii Nauk [Archive of the Russian Academy of Sciences] Register 350. Case 2. Inventory number 388.

8. "Nauka o religii", "nauchnyj ateizm", "religiovedenie": aktualnye problem nauchnogo izucheniya religii v Rossii XX - nachala XXI v. ["The science of religion"," scientific atheism”," religious studies": actual issues of the scientific study of religion in Russia XX - early XXI century] / Ed. K.M. Antonov. M.: PSTGU, 2014.

9. Arkhiv Rossiiskoi Akademii Nauk [Archive of the Russian Academy of Sciences] Register 350. Case 2. Inventory number 336.

10. Shakhnovich M.M. Sektsiya po izucheniyu religii narodov SSSR pri Muzee istorii religii Akademii nauk SSSR (1934 g.). [Section for Study of Religions of the USSR Nations at Museum of the History of Religion of Academy of Sciences of USSR]. Gosudarstvo, religiya i tserkov' v Rossii i za rubezhom, 2013. № 1. P.199-216.

11. Sankt-Peterburgskii Filial Arkhiva Rossiiskoi Akademii Nauk [St. Petersburg Branch of the Archive of the Russian Academy of Sciences]. Fund 221. Register 2. Inventory number 41.

\section{УДК 930.85}

\section{Религиоведение и антирелигиозная пропаганда в СССР в 1920-1930 гг.}

\author{
Марианна Михайловна Шахнович
}

Санкт-Петербургский государственный университет, Российская Федерация 199034 Санкт-Петербург, Менделеевская линия, д. 5

Доктор философских наук, профессор

E-mail: m.shakhnovich@spbu.ru

Аннотация. В статье показывается, что 1920-1930-е гг. в СССР одновременно с активной антирелигиозной пропагандой, проводились исследования по истории и антропологии религии, современным религиозным движениям, истории религиозного свободомыслия и атеизма. Систематическая работа по изучению религиозных верований и повседневных религиозных практик велась, как на основе масштабных полевых антропологических исследований, так и опираясь на достижения современных, в том числе 
и западных, теоретических трудов. В академическом сообществе тех лет существовало две группы авторов, пишущих о религии, но имеющих противоположные взгляды на природу и смысл самого изучения религии. Одна группа, пользуясь полученной возможностью проводить исследования в области религии без клерикальной цензуры, стремилась изучать религию как часть культуры, используя различные методологические подходы, включая марксизм и понимая выражение «критика религии» исключительно в философском смысле как исторический и социологический анализ. При этом, большинство из принадлежавших к этому кругу исследователей не отрицало марксистскую идею о постепенном исчезновении религии в секуляризированной мире. Другая группа - левые политические радикалы, которые стремились только разоблачать религию и искали основания для такого разоблачения. Среди работ, опубликованных по истории религии в советский период, следует различать работы, написанные исключительно с целью пропаганды, и научные труды, в которых творческие идеи и ценные научные достижения излагались в пределах идеологически возможных рамок конкретной эпохи.

Ключевые слова: религиоведение, антирелигиозная пропаганда в СССР, этнография, антропология. 